\title{
Electrochemical Study of Alkynyl Fe(II) Complexes
}

\author{
Ana I.F. Venâncio, ${ }^{\mathrm{a}}$ Luísa M.D.R.S. Martins ${ }^{\mathrm{a}, \mathrm{b}}$ Armando J.L. Pombeiro $^{\mathrm{a}}$ * \\ a) Centro de Química Estrutural, Complexo I, Instituto Superior Técnico, Av. Rovisco Pais, \\ 1049-001 Lisboa, Portugal. \\ ${ }^{b)}$ Secção de Química Inorgânica, DEQ, ISEL, R. Conselheiro Emídio Navarro, 1949-014 \\ Lisboa, Portugal
}

Received 10 September 2002; accepted in revised form 14 January 2003

\begin{abstract}
The behaviour of the neutral alkynyl complexes trans-[FeBr(L)(depe $\left.)_{2}\right](\mathrm{L}=-\mathrm{C} \equiv \mathrm{C}-$ $\mathrm{C}\left(=\mathrm{CH}_{2}\right) \mathrm{Ph} \mathbf{1} \boldsymbol{a},-\mathrm{C} \equiv \mathrm{C}-\mathrm{CPh}_{2}(\mathrm{H}) \mathbf{1} \boldsymbol{b}$; depe $\left.=\mathrm{Et}_{2} \mathrm{PCH}_{2} \mathrm{CH}_{2} \mathrm{PEt}_{2}\right)$ is studied by cyclic voltammetry and the electrochemical $P_{\mathrm{L}}$ and $E_{\mathrm{L}}$ ligand parameters for the alkynyl ligands are estimated showing that they behave as very strong net electron-donors.
\end{abstract}

Keywords: alkynyl, anodic behaviour, electrochemical ligand parameters, cyclic voltammetry.

\section{Introduction}

The tertiary propargylic alcohols, $\mathrm{HC} \equiv \mathrm{CC}(\mathrm{OH}) \mathrm{R}_{1} \mathrm{R}_{2}\left(\mathrm{R}_{1}, \mathrm{R}_{2}=\right.$ alkyl or aryl $)$, are very versatile species and by reaction with a metallic fragment they can be converted into vinylidene, allenylidene and alkynyl ligands. In particular the allenylidene complexes $(M=\mathrm{C}=\mathrm{C}=\mathrm{C} \quad)$ present an extended unsaturated carbon chain and are expected to be highly reactive species (chemically [1-3] and

\footnotetext{
* Corresponding author. E-mail address: pombeiro@ist.utl.pt
} 
electrochemically [4]) due to such a polyunsaturated system, and can lead to other unsaturated products, for example, alkynyl derivatives $(M-\mathrm{C} \equiv \mathrm{C}-\mathrm{C})$. The synthesis and characterization of the latter species are being reasonably explored, but their electrochemical behaviour has been investigated only very scarcely.

This work concerns the cyclic voltammetric study of alkynyl complexes obtained from cationic allenylidene species of Fe(II), i.e., the neutral alkynyl derivatives trans $-\left[\mathrm{FeBr}\left\{-\mathrm{C} \equiv \mathrm{C}-\mathrm{C}\left(=\mathrm{CH}_{2}\right) \mathrm{Ph}\right\}(\text { depe })_{2}\right] \quad \mathbf{1} \boldsymbol{a}\left(\right.$ depe $\left.=\mathrm{Et}_{2} \mathrm{PCH}_{2} \mathrm{CH}_{2} \mathrm{PEt}_{2}\right)$ and trans $-\left[\mathrm{FeBr}\left\{-\mathrm{C} \equiv \mathrm{C}-\mathrm{CPh}_{2}(\mathrm{H})\right\}(\text { depe })_{2}\right] \mathbf{1 b}$.

These compounds were obtained from the reaction of trans$\left[\mathrm{FeBr}\left(=\mathrm{C}=\mathrm{C}=\mathrm{CR}_{1} \mathrm{R}_{2}\right)(\text { depe })_{2}\right]\left[\mathrm{BPh}_{4}\right]\left(\mathrm{R}_{1}=\mathrm{Me}, \mathrm{R}_{2}=\mathrm{Ph} ; \mathrm{R}_{1}=\mathrm{R}_{2}=\mathrm{Ph}\right)[5]$ with an appropriate base or nucleophile [6]. The ligand parameters, $\mathrm{P}_{\mathrm{L}}$ and $\mathrm{E}_{\mathrm{L}}$, of the alkynyl ligands are also estimated, allowing to identify the donor/acceptor electronic properties of such ligands, which are compared with those of the parent allenylidenes in their precursor complexes [7].

\section{Results and discussion}

The electrochemical behaviour of the neutral alkynyl complexes trans$\left[\mathrm{FeBr}(\mathrm{L})(\text { depe })_{2}\right] \quad\left(\mathrm{L}=-\mathrm{C} \equiv \mathrm{C}-\mathrm{C}\left(=\mathrm{CH}_{2}\right) \mathrm{Ph} \quad \mathbf{1} \boldsymbol{a},-\mathrm{C} \equiv \mathrm{C}-\mathrm{CPh}_{2}(\mathrm{H}) \quad \mathbf{1} \boldsymbol{b}\right)$ has been investigated by cyclic voltammetry $(\mathrm{CV})$, in a $0.2 \mathrm{M}\left[\mathrm{NBu}_{4}\right]\left[\mathrm{BF}_{4}\right] / \mathrm{CH}_{2} \mathrm{Cl}_{2}$ solution, using a platinum-disc working electrode and an EG\&G Model 273A potentiostat/galvanostat connected to a PC computer through a GPIB interface (National Instruments PC-2A).

These complexes exhibit one reversible anodic wave (Table 1) at $\mathrm{E}_{\frac{1}{2}}{ }^{\text {ox }}=-0.06 \mathrm{~V}$ (1a) and $-0.13 \mathrm{~V}(\mathbf{1} \boldsymbol{b}) \quad v s$. S.C.E., assigned to the metal oxidation $(\mathrm{Fe}(\mathrm{II}) \rightarrow \mathrm{Fe}(\mathrm{III}))$, which is followed by a second one, at a more anodic potential $(1.14 \mathrm{~V}-1.19 \mathrm{~V})$ (Fig. 1).

Attempts to study these complexes by controlled potential electrolysis were unsuccessful due to the poisoning of the electrode surface by species formed in the anodic processes. 


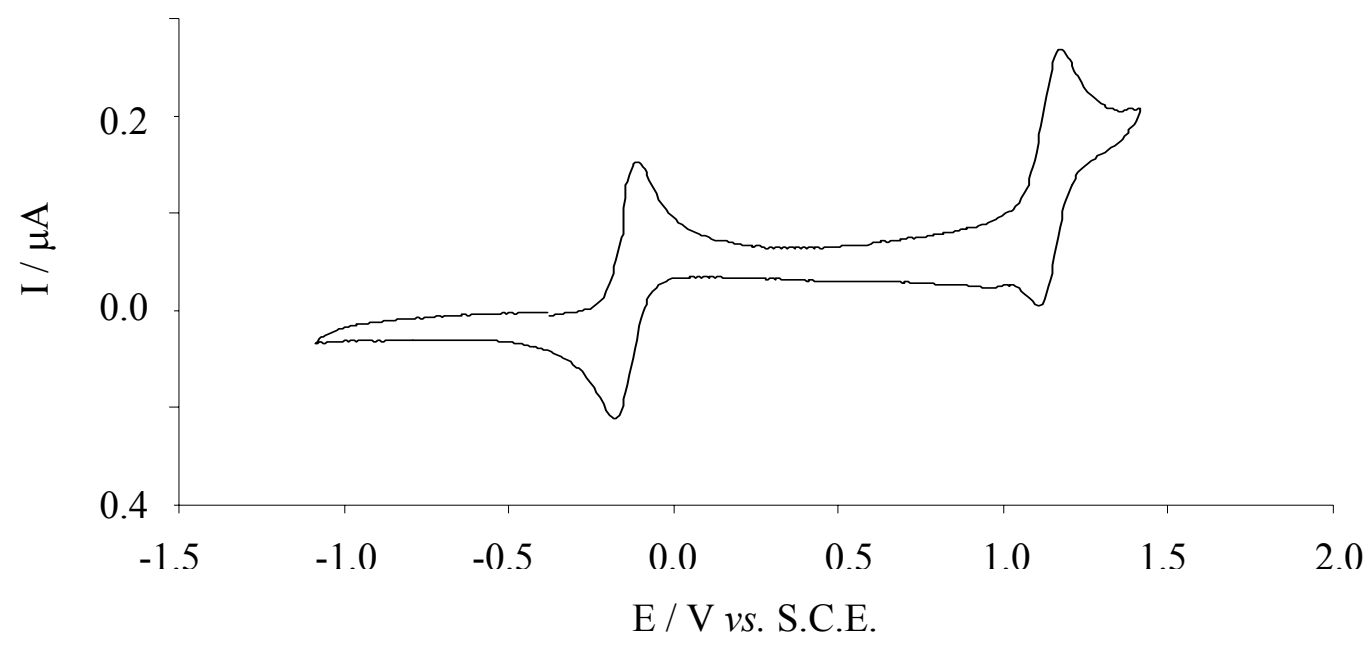

Figure 1. Anodic cyclic voltammogram, at $0.2 \mathrm{~V} . \mathrm{s}^{-1}$, for trans- $[\mathrm{FeBr}\{-\mathrm{C} \equiv \mathrm{C}-$ $\left.\left.\mathrm{CPh}_{2}(\mathrm{H})\right\}(\text { depe })_{2}\right] \mathbf{1 b}$ in a $0.2 \mathrm{M}\left[\mathrm{Bu}_{4} \mathrm{~N}\right]\left[\mathrm{BF}_{4}\right] / \mathrm{CH}_{2} \mathrm{Cl}_{2}$ solution, at a $\mathrm{Pt}$ disc working electrode.

Table 1. Anodic cyclic voltammetric data (first anodic wave) for the neutral alkynyl complexes trans-[FeBr(L)(depe $\left.)_{2}\right]^{a}{ }^{a}$

\begin{tabular}{cc}
\hline $\mathbf{L}$ & $\mathbf{E}_{1 / 2}^{\text {ox }}$ \\
\hline$-\mathrm{C} \equiv \mathrm{C}-\mathrm{C}\left(=\mathrm{CH}_{2}\right) \mathrm{Ph} \mathbf{1 a}$ & -0.06 \\
$-\mathrm{C} \equiv \mathrm{C}-\mathrm{CPh}_{2}(\mathrm{H}) \mathbf{1 b}$ & -0.13 \\
\hline
\end{tabular}

\footnotetext{
${ }^{a}$ Potential values in Volt \pm 0.02 vs. S.C.E. $\left(\right.$ scan rate $=0.2 \mathrm{~V}^{-1} \mathrm{~s}^{-1}$ ). The internal standard used was the redox couple $\left[\mathrm{Fe}\left(\eta^{5}-\mathrm{C}_{6} \mathrm{H}_{5}\right)_{2}\right]^{0 /+}$ $\left(\mathrm{E}_{1 / 2}^{\mathrm{ox}}=0.525 \mathrm{~V} v\right.$ s. S.C.E. $)$.
}

\section{Estimate of the ligand electrochemical parameters, $P_{L}$ and $E_{L}$}

The measured first oxidation potentials $\left(\mathrm{E}_{1 / 2}{ }^{\text {ox }}\right)$ of the alkynyl complexes, viewed as closed shell octahedral-type complexes $\left[\mathrm{M}_{\mathrm{S}} \mathrm{L}\right]$, with the alkynyl ligand (L) ligating the 16-electron $\left\{\mathrm{M}_{\mathrm{S}}\right\}=$ trans- $\left\{\mathrm{FeBr}(\mathrm{depe})_{2}\right\}^{+}$site, allow one to estimate (Table 2) the electrochemical $\mathrm{P}_{\mathrm{L}}$ ligand parameter (a measure of the net electron $\pi$-acceptor minus $\sigma$-donor character of a ligand), by applying to these complexes 
the linear expression (1) proposed by Pickett et al. [8] and considering the known [9] values of $E_{S}=1.32 \mathrm{~V}$ and $\beta=1.10$ for that iron(II) binding site.

$$
\mathrm{E}_{1 / 2}{ }^{o x}\left[\mathrm{M}_{\mathrm{S}} \mathrm{L}\right]=\mathrm{E}_{\mathrm{s}}+\beta \cdot P_{\mathrm{L}}
$$

where $E_{s}$ is the electron-richness of the metal site $\left\{M_{s}\right\}$ and $\beta$ is the polarisability of the metal site $\left\{\mathrm{M}_{\mathrm{s}}\right\}$.

Another redox potential parameterization approach for octahedral complexes was developed by Lever [10], who proposed an empirical relationship expressed by eq. (2) in which the redox potential (in volts vs. NHE) of a complex is related to electrochemical parameters determined by the ligands and the metal centre.

$$
\mathrm{E}_{1 / 2}^{\mathrm{ox}}=\mathrm{I}_{\mathrm{M}}+\mathrm{S}_{\mathrm{M}} \cdot\left(\Sigma E_{\mathrm{L}}\right)
$$

where: $\Sigma E_{\mathrm{L}}-$ sum of the values of the ligand $\mathrm{E}_{\mathrm{L}}$ parameter for all the ligands (additive effects); $\mathrm{S}_{\mathrm{M}}$ and $\mathrm{I}_{\mathrm{M}}$ - slope and intercept (dependent upon the metal, redox couple, spin state and stereochemistry).

The $\mathrm{P}_{\mathrm{L}}$ and $\mathrm{E}_{\mathrm{L}}$ ligand parameters are related by the empirical eq. (3), also proposed by Lever [10].

$$
P_{\mathrm{L}}(\mathrm{V})=1.17 \cdot E_{\mathrm{L}}-0.86
$$

The values for the Lever $E_{\mathrm{L}}$ ligand parameter (Table 2) were estimated from eq. (2), the known [10] values of $E_{L}$ for the other ligands, and $I_{M}$ and $S_{M}$ for the iron(II) centre. Identical values were obtained from eq. (3).

Table 2. Estimated $P_{\mathrm{L}}$ and $E_{\mathrm{L}}$ parameters for the alkynyl ligands.

\begin{tabular}{ccc}
\hline Ligand & $\boldsymbol{P}_{\mathbf{L}} / \mathbf{V}$ & $\begin{array}{c}\boldsymbol{E}_{\mathrm{L}} / \boldsymbol{V} \text { vs. } \\
\text { NHE }\end{array}$ \\
\hline$-\mathrm{C} \equiv \mathrm{C}-\mathrm{C}\left(=\mathrm{CH}_{2}\right) \mathrm{Ph} \mathbf{1 a}$ & -1.25 & -0.33 \\
$-\mathrm{C} \equiv \mathrm{C}-\mathrm{CPh}_{2}(\mathrm{H}) \mathbf{1 b}$ & -1.31 & -0.38 \\
\hline
\end{tabular}

The values of Table 2 indicate that $-\mathrm{C} \equiv \mathrm{C}-\mathrm{C}\left(=\mathrm{CH}_{2}\right) \mathrm{Ph}$ behaves as a stronger net $\pi$-electron acceptor minus $\sigma$-donor ligand than $-\mathrm{C} \equiv \mathrm{C}-\mathrm{CPh}_{2}(\mathrm{H})$.

In addition, the estimated $P_{\mathrm{L}}$ values are much lower than those of allenylidenes at the same metal centre $(-0.32$ to $-0.38 \mathrm{~V}[7])$, showing that the alkynyls behave as much stronger net electron donor ligands than the latter. 


\section{Final comments}

These results show that the alkynyl ligands present $\mathrm{E}_{\mathrm{L}}$ and $\mathrm{P}_{\mathrm{L}}$ values much lower than those of the corresponding allenylidenes, indicating that the former ligands are much better net electron donors than the latter. They are even slightly better donors than the aromatic alkynyl ligand $-\mathrm{C} \equiv \mathrm{C}-\mathrm{Ph}\left(\mathrm{P}_{\mathrm{L}}=-1.22 \mathrm{~V}\right)[11]$.

In contrast, carbyne ligands are very effective $\pi$-electron acceptors $[11,12]$ and therefore the net electron donor character of these types of ligands decreases with the increase of the metal-carbon bond order, as follows:

alkynyl $(M-\mathrm{C} \equiv \mathrm{C}-)$ (this work) $>$ allenylidene $(M=\mathrm{C}=\mathrm{C}=\mathrm{C}<)>$ carbyne $(M \equiv \mathrm{C}-)$

$$
\text { [7] > carbyne }(M \equiv \mathrm{C}-)[11,12]
$$

\section{Acknowledgements}

This work has been partially supported by the Fundação para a Ciência e Tecnologia (FCT), and the PRAXIS XXI and POCTI Programmes (Portugal).

\section{References}

1. V. Cadierno, M.P. Gamasa, J. Gimeno, Eur. J. Inorg. Chem. (2001) 571.

2. J.-F. Capon, N.Le Berre-Cosquer, F. Chuburu, R. Kergoat, J.-Y. Saillard, Inorg. Chim. Acta 250 (1996) 119.

3. C. Bianchini, M. Peruzzini, F. Zanobini, C. Lopez, I. de los Rios, A. Romerosa, Chem. Commun. (1999) 443.

4. S. Rigaut, O. Maury, D. Touchard, P.H. Dixneuf, Chem. Comm. (2001) 373.

5. A.I.F. Venâncio, L.M.D.R.S. Martins, J.J.R. Fraústo da Silva, A.J.L. Pombeiro, International School of Organometallic Chemistry, CamerinoItaly, 2001, p. 135.

6. A.I.F. Venâncio, L.M.D.R.S. Martins, J.J.R. Fraústo da Silva, A.J.L. Pombeiro, XXth International Conference on Organometallic Chemistry, Corfu, Greece, p. 187. 
7. A.I.F. Venâncio, L.M.D.R.S. Martins, J.J.R. Fraústo da Silva, A.J.L. Pombeiro, Port. Electrochim. Acta 19 (2001) 361.

8. J. Chatt, C.T. Khan, G.J. Leigh, C.J. Pickett, D.R. Stanley, J. Chem. Soc., Dalton Trans. (1980) 2032.

9. M.F.C. Guedes da Silva, L.M.D.R.S. Martins, J.J.R. Fraústo da Silva, A.J.L. Pombeiro, Collect. Czech. Chem. Commun. 66 (2001) 139.

10. A.B.P. Lever, Inorg. Chem. 29 (1990) 1271.

11. A.J.L. Pombeiro, New. J. Chem. 21 (1997) 649.

12. L. Zhang, M.F.C. Guedes da Silva, M.L. Kuznetsov, M.P. Gamasa, J. Gimeno, J.J.R. Fraústo da Silva, A.J.L. Pombeiro, Organometallics 20 (2001) 2782. 